\title{
Lean Management, Competitive Advantage, and Firm Performance: The Role of Management Control Systems (Evidence from Indonesia Manufacturing Firms)
}

\author{
Kevin Hermanto Tupamahu \\ Ph.D. Student at the Faculty of Economics and Business, \\ Diponegoro University, Semarang, Indonesia / \\ Lecturer at Faculty of Teacher Training and Education, \\ Pattimura University, Ambon, Indonesia \\ Imam Ghozali \\ Lecturer at Faculty of Economics and Business, \\ Diponegoro University, Semarang, Indonesia \\ P.T. Basuki HP \\ Lecturer at Faculty of Economics and Business, \\ Diponegoro University, Semarang, Indonesia
}

Doi: 10.36941/ajis-2019-0020

\begin{abstract}
The purpose of this paper is to examine the role of management control systems (MCS) to support the implementation of lean management strategy to achieve competitive advantage and improve firm performance. Data collected using a questionnaire survey. A total of 123 managers in manufacturing firms participated in this study. Data were analyzed using structural equation models. The results show that a lean management strategy is positively and significantly related to MCS and competitive advantage; MCS has a positive and significant effect on competitive advantage and firm performance. Furthermore, these results show that MCS serves as a mediating variable to the relationship between lean management and competitive advantage, and firm performance. The results of the study show the role of lean MCS as an integral part of lean management to achieve competitive advantage and improve firm performance. This result is the initial evidence of how MCS mediates the relationship between lean management strategy, competitive advantage, and firm performance.
\end{abstract}

Keywords: lean management, management control systems (MCS), competitive advantages, firm performance

\section{Introduction}

Over the past three decades, lean management has been proven as a successful business strategy in achieving world-class manufacturing performance (e.g., Fullerton et al., 2014; Fullerton \& Wempe, 2009; Lewis, 2000; Marodin et al., 2016; Nawanir et al., 2013; Shah \& Ward, 2003). Lean management is recognized as a business system that combines various lean tools to help identify and consistently eliminate waste to improve quality, flexibility, responsiveness, production time and reduce costs (F. A. Kennedy \& Widener, 2008; Wilson, 2010). This is seen as a way for firms to create customer value to build and maintain the position of their products in competitive markets (Flynn et al., 1995). That is carried out by integrating all business processes through the application 
of lean management strategies and it is needed to be supported by an appropriate Management Control Systems (MCS) (Ahlstrom \& Karlsson, 1996; F. A. Kennedy \& Widener, 2008).

MCS plays a central role in providing fundamental controls for internal decision making and all operational activities in lean organizations. Although, in the management accounting literature, many studies link strategy and MCS, studies that specifically discuss MCS integration with lean management strategies and their impact on organizational outcomes are still limited (Fullerton et al., 2013, 2014; Netland et al., 2015). In addition, there is an argument that stated that once employees are fully trained and operated based on lean principles, they are fully guided by the process of operating activities and intrinsically motivated to make the right decisions, which in turn, MCS is no longer needed in lean organizations (F. Kennedy \& Brewer, 2007). The purpose of this study is to investigate this issue, by examining the use of MCS that aligned with lean principles in supporting the implementation of lean management strategies and their impact on achieving competitive advantage and improving firm performance.

\section{Literature Review and Hypothesis Development}

Lean management has become a philosophy and even an ideology for the firms that want to achieve success. Lean management is referred to as an integrated socio-technical system in which its primary goal is to eliminate waste by reducing or minimizing internal variability, customers and suppliers (Shah \& Ward, 2007). The key focus of the application of lean management is the creation of value through continuous improvement and eliminating waste (Womack \& Jones, 2003). This will be enormously beneficial for the firm because that will create an effective and efficient production process, and enabling the firm to respond quickly to customer needs. A combination of various lean tools such as just in time (JIT), total quality management (TQM), and statistical control has proven to be positively related to increasing competitive advantage in the form of quality improvement, delivery, flexibility, and cost reduction (Flynn et al., 1995; Wood et al., 2004; Youssef \& Youssef, 2015).

From the perspective of Resource-Based View (RBV), competitive advantage can be achieved depending on the firm's ability to manage its resources (Wernerfelt, 1984). Resources are intended as valuable assets (tangible and intangible), cannot be replicated, rare, and cannot be exchanged (Amit \& Schoemaker, 1993; J. Barney, 1991). Resources include a variety of elements like physical assets, human resources, organizational assets, and competencies (Amit \& Schoemaker, 1993; J. Barney, 1991; Henri, 2006). Competitive advantage will be obtained when the owned resources allow the organization to implement strategies to increase the effectiveness and efficiency of the organization (see., J. Barney, 1991; J. B. Barney, 1986). Henri (2006) stated MCS was a valuable, rare, and inimitable organizational resource that is important for firms in achieving competitive advantage and high performance.

This research views that the MCS as an integral part of all business activities that play an important role in supporting the entire lean strategies implementation in achieving competitive advantage. In this study, MCS consists of three control dimensions that are deemed in line with lean principles. First, in lean organizational environments, performance information is no longer reported to use complicated historical reports but is reported visually on display boards provided at each work stations. This makes visual performance measurement as a critical part of MCS (B. H. Maskell \& Kennedy, 2007). Visual performance measurement provides the availability and visibility of information strategically aligned with performance measurement information at the shop-floor level, as the basis for decision making in operating activities. Second, lean organizations require standardized procedures that display the entire picture of the production process and are used to ensure a continuous flow of consistent products (F. A. Kennedy \& Widener, 2008). The use of standard operating procedures (SOP) shows that standards are always updated continuously and are used to ensure that the behavior of organizational members to experience continuous improvement in a better direction and no longer returns to old habits (Kristensen \& Israelsen, 2014). Third, the success of lean organizations is primarily dependent on the creation of a participatory organizational culture where employees are trained across functions and are responsible for improvements related to decision making and quality of output within the firm. This makes 
empowering employees as an essential element of MCS (Fullerton et al., 2013).

Although some literature has noted the importance of the role of MCS (see., F. A. Kennedy \& Brewer, 2006; B. H. Maskell \& Baggaley, 2006), empirical evidence that specifically links lean management strategies and MCS, and their effects on competitive advantage and firm performance is still very limited. However, several studies have examined the relationship between firm performance, competitive advantage, the use of non-financial performance measurement, and lean practices. For example, Perera et al. (1997) found that changes in MCS in the form of the use of non-financial performance measures in firms that have adopted a customer-focused manufacturing strategy do not affect firm performance. The same was found by Callen et al. (2000) that the use of non-financial performance measures is uninfluential in improving performance in firms that adopt JIT and do not adopt JIT. On the other hand, Fullerton and Wempe (2009) and Fullerton et al. (2014) found that using MCS that aligned with lean manufacturing had a positive effect on firm performance. Furthermore, Chenhall (2005) also found that the use of integrated performance measurements that are aligned with strategic objectives has a positive relationship with competitive advantages.

The results of previous studies indicate that there is still mixed evidence relating to the use of non-traditional MCS in the form of non-financial performance measurement, its relationship with lean management, and its influence on competitive advantage and firm performance. Furthermore, the results of previous research additionally have not provided direct evidence of how MCS that is specified align with lean goals that influence competitive advantage and firm performance. Therefore, this study focuses on examining whether the application of lean management can achieve success by focusing solely on the application of lean tools, or the firm requires MCS to be able to maximize the benefits derived from the implementation of lean management. The relationship between variables in this study is shown in the empirical framework in Figure 1.

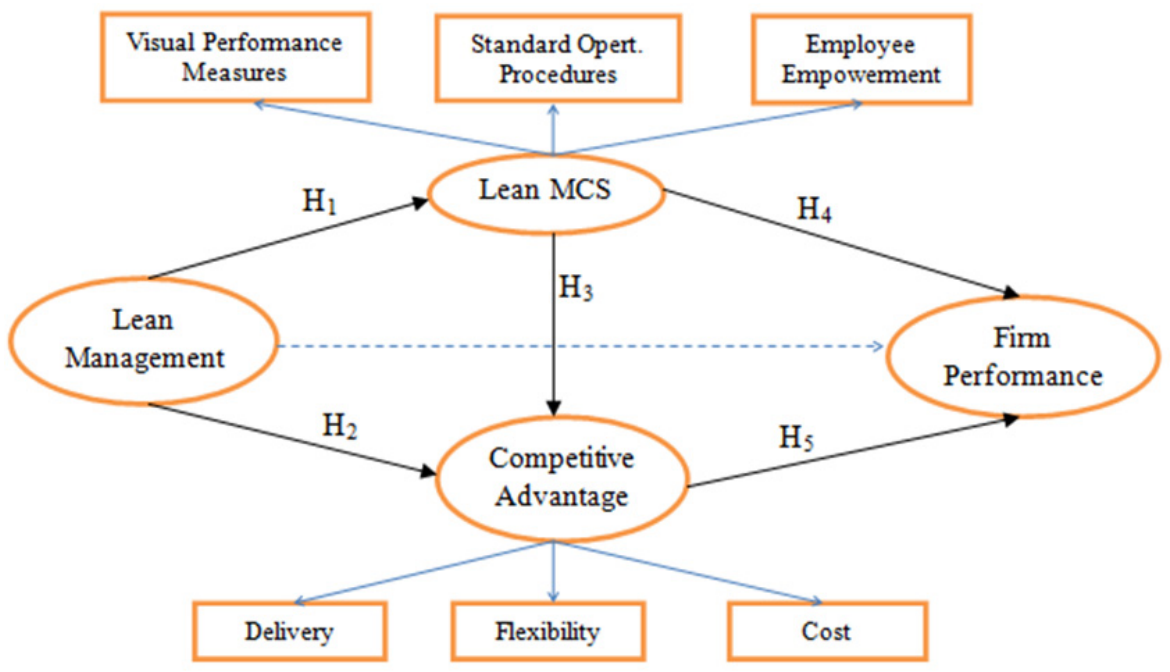

Figure 1. Theoretical model. Note: The dotted line represents the control path. The solid lines represent the hypothesized paths.

\subsection{Lean management and MCS}

Previous studies indicated that implementing MCS that aligned with lean principles (such as visual performance measurement, SOP, and employee empowerment) will maximize the benefits derived from implementing lean management. For example, performance measurement visually supports lean implementation by presenting information in a visible, timely, simple and relevant manner to be 
used by shop-floor employees to ensure that the goals of lean management are met (Fullerton et al., 2013, 2014). SOP displays production lines that are documented in the form of images and text and are used to ensure a continuous flow of consistent products with lean goals (F. A. Kennedy \& Widener, 2008). Employee empowerment supports the implementation of lean management strategies as a mechanism of social control (Bhasin, 2012; Fullerton et al., 2013; Hu et al., 2015). Effective empowerment makes workers have the knowledge and expertise to be used in their decision-making and actions to achieve key success factors inherent in lean management (B. Maskell et al., 2012). Based on previous arguments and research described above, the following hypotheses are formulated as follows:

$\mathrm{H} 1$ : The implementation of lean management strategies is positively related to MCS

\subsection{Lean management and competitive advantage}

Competitive advantage is a functional form, as the goal of a business strategy implementation. In other words, competitive advantage is the result of the applied business strategy. The type of competitive advantage that firms choose to emphasize depends on the type of business strategy chosen. Applied manufacturing strategies must be able to support operations and improve the capacity to achieve high quality, fast delivery, production flexibility, and low costs. Implementation of Lean management strategy facilitates increased shipment punctuality by ensuring that suppliers are on high quality and be able to deliver on time, therefore, it reduces the cycle of production without delay due to defects. Flexibility of operations and to respond quickly to customer needs is also one of the advantages given by lean management strategies (F. A. Kennedy \& Widener, 2008). The application of lean principles will encourage the creation of labor efficiency, reduction in product cycle time, lead-time and inventory reduction, which leads to lower costs and increased flexibility (Ruiz-de-Arbulo-Lopez et al., 2013). In sum, the application of lean management strategies will encourage increased the ability to make effective and efficient production and enable firms to respond and meet customer needs quickly. Therefore, the hypothesis is formulated as follows:

$\mathrm{H} 2$ : Implementation of lean management strategies has a positive effect on competitive advantage.

\subsection{The relationship between MCS and competitive advantage}

Researchers and practitioners have indicated that forms of control like a visual performance measurement, SOP, and employee empowerment have an impact on achieving competitive advantage. Visual performance measurement provides information on time, clearly related to strategic objectives, and easily comprehended by employees (Fullerton et al., 2013). It helps to ensure the creation of quality products and on-time deliveries that are suitable for customer needs (B. Maskell et al., 2012). Fullerton et al. (2014) also found that the use of visual performance measurements shortened cycle times, rework, and waiting times. These results indicate that information on performance measures displayed visually will increase production flexibility.

Furthermore, the SOP provides standard guidelines for workers to be able to coordinate with each other in operations, as well as to improve work effectiveness and efficiency. Standardization will provide benefits to reduce response time to increase shipping, minimize the error rate in the production process, and increase the competitiveness of firms in terms of prices (Rondeau et al., 2000). Also, SOP regulates customer order processing, ordering materials, testing products, and providing contingency scenarios that help ensure quality and flexibility in the production process ( $F$. A. Kennedy \& Widener, 2008). It helps monitor flows in all operational activities to ensure quality achieved consistently. Empowerment creates a workforce that is driven by increased knowledge and ability to produce quality products or services. Empowerment will make employees participate effectively to make quick and precise decisions, which in turn, facilitate the achievement of firm goals (Fullerton \& McWatters, 2002; F. A. Kennedy \& Widener, 2008). Based on the discussion and previous research provided above, the following hypothesis formulated:

H3: MCS is positively related to competitive advantage 


\subsection{The relationship between MCS and firm performance}

In a lean organizational environment, MCS in the form of visual performance measurement, SOP, and employee empowerment work together as a control package to improve firm performance (Kristensen \& Israelsen, 2014). Visual performance measurement provides information feedback in a relatively fast time and is easily understood by workers displayed visually through a display board (B. H. Maskell \& Kennedy, 2007). The feedback communicated becomes a reference for employees to make improvements in operational activities. Fullerton et al. (2014) revealed that firm performance will increase significantly when every information is always available on the work stations related to product quality, easy to understand, and in line with lean goals.

SOP documented each step of the operational process in the form of chart and text ( $F$. Kennedy \& Brewer, 2007), which shows a systematic description of value-added and non-valueadded activities that can be observed by everyone in manufacturing cells (Kristensen \& Israelsen, 2014). This not only helps to standardize work but also sets limits on decision making in operating activities, so that it can ensure every action taken by employees will create continuous improvements that lead to improved firm performance. Furthermore, empowering employees will increase employee motivation to do their works well. High empowerment will direct employees to great effort and intensity their efforts, perseverance, and flexibility (Spreitzer, 1995; Thomas \& Velthouse, 1990), which in turn, consistently increased organizational performance (F. Kennedy \& Brewer, 2007). Under this discussion and the results of previous studies, the following hypothesis is formulated:

$\mathrm{H} 4$ : MCS is positively related to firm performance

\subsection{The relationship between competitive advantage and firm performance}

Firms that have competitive advantages show that they have higher grades than their competitors in terms of high quality, on-time delivery, high flexibility, and low cost. Li et al. (2006) stated that competitive advantage will bring firms to a higher level of economic performance, effective relationships, loyalty, and customer satisfaction. Firms that offer high-quality products will have a high reputation in the market, can reduce costs, and have high productivity (Amoako-Gyampah \& Acquaah, 2008), which in turn increases market share, sales profit margins and return on investment (Li et al., 2006). Quick and precise delivery time will make firms win orders because they are the first in the market so they can have higher market share and sales (Chi et al., 2009). High flexibility in the production process will enable the firm to respond quickly to any changes in the market to create performance improvements. While the ability to create low production costs to produce products at relatively low prices will increase efficiency and leading to increased market share and sales growth. In sum, firms that have competitive advantages show that firms gain more capabilities than their competitors. The competitive advantage owned as a firm's ability that will ultimately improve firm performance. Based on the discussion above, the hypothesis is formulated as follows:

H5: Competitive advantage is positively related to firm performance.

\section{Research methodology}

\subsection{Sample and data collection}

The population of this study is a manufacturing firm that has implemented a quality management system as evidenced by ownership of ISO 9001 certification, which is an international standard for quality management systems. It used as a criterion for firms that have begun to apply the concept of lean management in firm operations (King \& Lenox, 2001). Samples are represented by managers, assuming that they are people who truly understand the strategies, operating activities and implementation of the firm's MCS. Data from manufacturing firms in Indonesia are obtained from idx.co.id. This study uses survey techniques to collect data. The questionnaires were collected and fulfilled the criteria to be analyzed in this study were 123 (response rate of $20.5 \%$ ). Table 1 below shows the characteristics of respondents. 
Table 1: Characteristics of Respondents

\begin{tabular}{|c|c|c|c|}
\hline Characteristics of Respondents & Number of responses & Classification & Total \\
\hline & & Accounting / Finance Manager & 58 \\
\hline & & Head of Accounting \& Finance Division & 8 \\
\hline & & Head of Manufacturing Division & 6 \\
\hline \multirow[t]{5}{*}{ Position } & 123 & Planning /Production Manager & 35 \\
\hline & & HR Manager & 10 \\
\hline & & General Manager & 5 \\
\hline & & Director & 1 \\
\hline & & $0-10$ years & 32 \\
\hline \multirow[t]{2}{*}{ Period of Work Experience } & 123 & $11-20$ years & 53 \\
\hline & & $>20$ years & 38 \\
\hline \multirow{3}{*}{ Period of Position Experience } & 1 & $2-5$ years & 66 \\
\hline & 1200 & $>5$ years & 57 \\
\hline & & $<250$ Employees & 22 \\
\hline \multirow[t]{2}{*}{ Number of Employees } & 123 & $250-100$ Employees & 39 \\
\hline & & $>1000$ Employees & 62 \\
\hline
\end{tabular}

Non-response bias is tested by comparing questionnaires returned earlier before the cut-off date with the last after the cut-off date. Overall, the results showed there is no non-response bias ( $p$ value $>0.05$ ) (Table 2).

Table 2: Non-response bias

\begin{tabular}{lcc}
\hline Construct & Early respondents $(\mathrm{n}=58)$ & Late respondents $(\mathrm{n}=28)$ \\
\hline Early Respondents vs Late Respondent & & \\
Lean Management & & 35,25 \\
Visual Performanace Measurement & 34,52 & $\mathbf{3 3 , 8 6}$ \\
Employee Empowerment & 29,69 & $\mathbf{2 9 , 8 6}$ \\
Standard Operating Procedures & 24,03 & $\mathbf{2 5 , 2 5}$ \\
Delivery & 23,71 & $\mathbf{2 3 , 2 5}$ \\
Flexibilty & $\mathbf{1 6 , 1 0}$ & $\mathbf{1 6 , 2 5}$ \\
Cost & $\mathbf{8 , 3 3}$ & $\mathbf{8 , 5 7}$ \\
Firm Performance & $\mathbf{2 3 , 7 1}$ & $\mathbf{2 4 , 8 6}$ \\
\hline a The sample was divided into early, middle, and late respondents based on return date of survey \\
questionnaire.
\end{tabular}

\subsection{Variable measurement}

Lean management (LM) in this study was measured using nine elements that represent the implementation of lean concepts in manufacturing environments, including standardization, manufacturing cells, lead time reduction, kanban systems, one-peace flow, lot size reduction, 5S concept, and kaizen (Fullerton et al., 2013). MCS is conceptualized as a second-order construct with three sub-dimensions: visual performance measurement (VPM), standard operating procedures (SOP), and employee empowerment (EEmp). Visual performance measurement instruments adapted from Fullerton et al. (2013) which consists of eight items including available information, information that is aligned with operational and strategic objectives, and information in visual form. The measures of employee empowerment adapted from Fullerton et al. (2013) which consists of seven items including employee involvement and training in problem-solving and improvement initiatives. The SOP measurement is adapted from Kristensen and Israelsen (2014) which consists of six items includes standardization and work mapping.

Competitive advantage (CA) is conceptualized as a second-order construct with three subdimensions: quality/delivery, flexibility, and cost. The measure of competitive advantage was adapted from Chenhall (2005) which consisted of eleven items. Finally, firm performance (FP) in this study was measured using subjective performance measurements. This measure consists of six items including financial performance, sales growth, market share, delivery system productivity, 
and overall performance (Widener, 2007; Yang et al., 2011).

\section{Result}

The analysis of the structural equation model (SEM) using the WarpPLS version 5.0 programs was used to test the hypothesis in this study. PLS-SEM is used as an analysis tool because it has several advantages (Hair Jr et al., 2014; Kock, 2010, 2011). First, PLS-SEM can be more efficiently estimate complex models with small samples as in this study. Second, PLS-SEM can simultaneously test multiple dependencies as in this research model. Third, PLS-SEM is aligned with this research model that uses variables that cannot be measured directly (unobserved variable/latent variable). This study uses a two-stage approach to determine the validity of measurements and then estimate the structural model (Ringle et al., 2012).

\subsection{Confirmatory factor analysis (CFA)}

Confirmatory factor analysis (CFA) was conducted to determine whether each measurement used in measuring the constructs had satisfactory psychometric properties (Fornell \& Larcker, 1981). Evaluation of measurement models refers to reliability indicator values, internal consistency reliability, convergent validity, and discriminant validity (Hair Jr et al., 2014). Assessment of firstorder contract measurement models confirms the fulfillment of reliability indicators for lean management (LM), management control systems (MCS), competitive advantage (CA), firm performance (FP) with factor loading values for all items above 0.70 (see ., Table 4). Except, for delivery constructs (factor I item 1) and flexibility constructs (factor II item 11), the loading factor values are 0.568 and $0.439(<0.70)$ respectively, so that they are excluded from the analysis for the next stage. Internal consistency reliability was assessed by calculating composite reliability. All measures of composite reliability are above 0.70 for adequate internal consistency reliability. The assessment of convergent validity constructs uses the value of the average variance extracted (AVE). Table 4 shows that all variables above the criteria of 0.50 for adequate convergent validity. Furthermore, Table 5 shows that all AVE square roots for each construct are greater than the correlation between constructs which proves satisfying discriminant validity (Hair Jr et al., 2014).

Table 4: Factor Loadings for LM, MCS, CA, and FP

\begin{tabular}{|c|c|c|c|}
\hline Panel A. Lean Management (LM) & \multicolumn{3}{|l|}{ Factor Loadings } \\
\hline Standardization & \multicolumn{3}{|l|}{0.786} \\
\hline manufacturing cells & \multicolumn{3}{|l|}{0.783} \\
\hline reduced setup times & \multicolumn{3}{|l|}{0.771} \\
\hline sistem kanban & \multicolumn{3}{|l|}{0.786} \\
\hline one-piece flow & \multirow{2}{*}{\multicolumn{3}{|c|}{$\begin{array}{l}0.842 \\
0.859\end{array}$}} \\
\hline reduced lot sizes & & & \\
\hline reduced buffer inventories & \multicolumn{3}{|l|}{0.883} \\
\hline $5 \mathrm{~s}$ & \multicolumn{3}{|l|}{0.837} \\
\hline kaizen (continuous improvement) & \multicolumn{3}{|l|}{0.784} \\
\hline Composite reliability & \multirow{2}{*}{\multicolumn{3}{|c|}{0.947}} \\
\hline AVE & \multicolumn{2}{|l|}{0.665} & \\
\hline Panel B. MCS & Factor Loadings 1 & Factor Loadings 2 & Factor Loadings 3 \\
\hline \multicolumn{4}{|l|}{ I. VPMs } \\
\hline collecte shop floor & \multicolumn{3}{|l|}{0.820} \\
\hline aligned measures & \multicolumn{3}{|l|}{0.766} \\
\hline visual boards & \multicolumn{3}{|l|}{0.778} \\
\hline quality info & \multicolumn{3}{|l|}{0.820} \\
\hline defect charts & \multicolumn{3}{|l|}{0.823} \\
\hline visual organization & \multicolumn{3}{|l|}{0.707} \\
\hline productivity info & \multicolumn{3}{|l|}{0.826} \\
\hline data work stations & \multicolumn{3}{|l|}{0.761} \\
\hline
\end{tabular}




\begin{tabular}{|c|c|c|c|}
\hline Panel B. MCS & Factor Lodiang I & Factor Loading II & Factor Loading III \\
\hline Composite reliability & 0.929 & & \\
\hline AVE & 0.622 & & \\
\hline \multicolumn{4}{|l|}{ II. EEmp } \\
\hline cross train & & 0.757 & \\
\hline quality decisions & & 0.760 & \\
\hline quality training & & 0.797 & \\
\hline training resources & & 0.720 & \\
\hline emply suggestions & & 0.812 & \\
\hline quality recognation & & 0.826 & \\
\hline Involvment & & 0.727 & \\
\hline Composite reliability & & 0.912 & \\
\hline AVE & & 0.596 & \\
\hline \multicolumn{4}{|l|}{ III. SOPs } \\
\hline work studies and diagrams & & & 0.790 \\
\hline standard continuously update & & & 0.786 \\
\hline value added & & & 0.815 \\
\hline current state maps & & & 0.834 \\
\hline action plans & & & 0.837 \\
\hline Mapping & & & 0.834 \\
\hline Composite reliability & & & 0.923 \\
\hline AVE & & & 0.666 \\
\hline \multicolumn{4}{|l|}{ Panel C. CA } \\
\hline \multicolumn{4}{|l|}{ I. Delivery/Quality } \\
\hline high quality product (1) & 0.568 & & \\
\hline fast deliveries (7) & 0.738 & & \\
\hline dependable delivery promises (8) & 0.823 & & \\
\hline effective after-sales service (9) & 0.837 & & \\
\hline product availability (10) & 0.828 & & \\
\hline Composite reliability & 0.874 & & \\
\hline AVE & 0.586 & & \\
\hline \multicolumn{4}{|l|}{ II. Flexibility } \\
\hline product features (3) & & 0.756 & \\
\hline design and new product (5) & & 0.860 & \\
\hline rapid volume and product mix (6) & & 0.848 & \\
\hline customise product and service (11) & & 0.439 & \\
\hline Composite reliability & & 0.826 & \\
\hline AVE & & 0.555 & \\
\hline \multicolumn{4}{|l|}{ III. Cost } \\
\hline low production costs (2) & & & 0.809 \\
\hline low price (4) & & & 0.809 \\
\hline Composite reliability & & & 0.791 \\
\hline AVE & & & 0.655 \\
\hline Panel D. Firm Performance (FP) & Factor Loadings & & \\
\hline Return on Sales & 0.914 & & \\
\hline Return on Investment & 0.884 & & \\
\hline relative market share & 0.721 & & \\
\hline sales growth & 0.862 & & \\
\hline Productivity & 0.847 & & \\
\hline overall performance & 0.905 & & \\
\hline Composite reliability & 0.943 & & \\
\hline AVE & 0.736 & & \\
\hline
\end{tabular}


Table 5: Square roots of AVE and correlations among first-order construct

\begin{tabular}{ccccccccc}
\hline & \multirow{2}{*}{ LM } & \multicolumn{9}{c}{ MCS } & & & CA & \multirow{2}{*}{ FP } \\
\cline { 3 - 7 } & & VPMs & EEmp & SOPs & Delv & Flex & Cost & \\
\hline LM & $\mathbf{( 0 . 8 1 5 )}$ & & & & & & & \\
\hline MCS: & & & & & & & & \\
VPM & 0.696 & $\mathbf{( 0 . 7 8 9 )}$ & & & & & & \\
EEmp & 0.567 & 0.758 & $\mathbf{( 0 . 7 7 2 )}$ & & & & & \\
SOP & 0.594 & 0.679 & 0.770 & $\mathbf{( 0 . 8 1 6 )}$ & & & & \\
\hline CA: & & & & & & & & \\
Dellivery & 0.550 & 0.560 & 0.563 & 0.588 & $\mathbf{( 0 . 7 6 6 )}$ & & \\
Flexibility & 0.479 & 0.467 & 0.499 & 0.552 & 0.591 & $\mathbf{( 0 . 7 4 5 )}$ & \\
Cost & 0.256 & 0.298 & 0.201 & 0.348 & 0.353 & 0.627 & $\mathbf{( 0 . 8 0 9 )}$ & \\
\hline FP & 0.465 & 0.603 & 0.512 & 0.567 & 0.454 & 0.406 & 0.461 & $\mathbf{( 0 . 8 5 8 )}$ \\
\hline
\end{tabular}

Note: square roots of AVE show on diagonal

The next stage is the assessment of the second-order contract measurement model for MCS and competitive advantage (see., table 6). The results confirm that the MCS construct meets the indicator reliability criteria with a factor loading above 0.70 . For internal consistency reliability, convergent validity, and discriminant validity for MCS constructs are also fulfilled with composite reliability above 0.70 , AVE values above 0.50 , and AVE square root greater than the correlation value between constructs. This result shows that VPMs, EEmps, and SOPs are constructors of the MCS second-order construct. For the second-order construction measurement model, competitive advantage also confirms that all measurements are met for all criteria with a loading factor above 0.70 , composite reliability above 0.70 , AVE above 0.50 , and square root AVE greater than value correlation between constructs. These results indicate that the variables of delivery, flexibility, and low cost constructs the second-order variable of competitive advantage.

Table 6: The Result of CFA for second-order construct MCS and CA

\begin{tabular}{|c|c|c|c|c|}
\hline Panel A. MCS & \multicolumn{4}{|c|}{ Factor Loadings } \\
\hline VPMs & \multicolumn{4}{|c|}{0.890} \\
\hline EEmp & \multicolumn{4}{|l|}{0.930} \\
\hline SOPs & \multicolumn{4}{|l|}{0.899} \\
\hline Composite reliability & \multicolumn{4}{|l|}{0.934} \\
\hline Cronbach's alpha & \multicolumn{4}{|l|}{0.893} \\
\hline AVE & \multicolumn{4}{|l|}{0.824} \\
\hline Panel B. CA & \multicolumn{4}{|c|}{ Factor Loadings } \\
\hline Delivery & \multicolumn{4}{|l|}{0.760} \\
\hline Flexiblity & \multicolumn{4}{|l|}{0.896} \\
\hline Cost & \multicolumn{4}{|l|}{0.818} \\
\hline Composite reliabilty & \multicolumn{4}{|l|}{0.866} \\
\hline Cronbach's alpha & \multicolumn{4}{|l|}{0.765} \\
\hline AVE & \multicolumn{4}{|l|}{0.683} \\
\hline \multicolumn{5}{|c|}{ Square roots of AVE and correlations among second-order construct } \\
\hline & LM & MCS & $\mathrm{CA}$ & FP \\
\hline$\overline{\mathrm{LM}}$ & (0.815) & & & \\
\hline MCS & 0.681 & (0.908) & & \\
\hline $\mathrm{CA}$ & 0.519 & 0.572 & $(0.827)$ & \\
\hline FP & 0.465 & 0.617 & 0.507 & $(0.858)$ \\
\hline Adjusted R-square & & 0.460 & 0.347 & 0.402 \\
\hline Q-Square & & 0.464 & 0.364 & 0.423 \\
\hline
\end{tabular}

\subsection{Hypothesis testing}

The results of evaluating structural models in Table 7 shows that the values of average path 
coefficient (APC), average R-squared (ARS) and average adjusted R-square (AARS) statistically significant $(p<0.05)$ with the respective APC values $=0.342$, ARS $=0.413$, and AARS $=0.403$. The criteria for average block VIF (AVIF) and average full collinearity VIF (AFVIF) show a value smaller than 3.3 which means that there are no multicollinearity problems between indicators and between exogenous variables. The value of the goodness tenancy (GoF) is greater than 0.36 which indicates that the fit model is included in the large category. For the index values of Sympson's paradox ratio (SPR), R-square contribution (RSCR), statistical suppression ratio (SSR), and nonlinear bivariate causality direction ratio (NLBCDR), each shows a value greater than 0.70 which confirms there are no causality problems in the research model. Thus, the assessment of fit criteria for structural models in this study has been fulfilled (Hair Jr et al., 2014).

The results of the structural model analysis can be seen in Table 7 and Figure 2. The implementation of lean management strategies is positively related to the use of lean MCS with a regression coefficient of 0.61 and significant $(p<0.01)$, which provides support for $H 1$. This result is in line with previous studies that reported that the use of MCS that aligned with lean principles was appropriate to support the application of lean management strategies (e.g., Ahlstrom \& Karlsson, 1996; Fullerton et al., 2013, 2014; F. A. Kennedy \& Widener, 2008). The structural model also supports $\mathrm{H} 2$; the application of lean management strategies is positively related to competitive advantage $(p<0.05)$. This is consistent with Flynn et al. (1995) and Youssef and Youssef (2015) who's found that firms can achieve a competitive advantage when implementing lean management practices.

Table 7: Structural Equation Model Result

\begin{tabular}{|c|c|c|c|c|c|}
\hline Relationship & Hypothesis & Direct Effect & Indirect Effect & Total Effect & Hypothesis \\
\hline $\mathrm{LM} \rightarrow \mathrm{MCS}$ & $\mathrm{H} 1$ & $0.681^{* * *}$ & & $0.681^{* * *}$ & Supported \\
\hline $\mathrm{LM} \rightarrow \mathrm{CA}$ & $\mathrm{H} 2$ & $0.241^{\star *}$ & $0.277^{\star * *}$ & $0.519^{\star \star *}$ & Supported \\
\hline $\mathrm{MCS} \rightarrow \mathrm{CA}$ & H3 & $0.407^{\star * *}$ & & $0.407^{\star \star \star *}$ & Supported \\
\hline $\mathrm{MCS} \rightarrow \mathrm{FP}$ & $\mathrm{H} 4$ & $0.470^{\star * *}$ & $0.091^{* *}$ & $0.561^{* * *}$ & Supported \\
\hline $\mathrm{CA} \rightarrow \mathrm{FP}$ & H5 & $0.224^{* * *}$ & & $0.224^{* * *}$ & Supported \\
\hline $\mathrm{LM} \rightarrow \mathrm{FP}$ & $\mathrm{NH}$ & 0.029 & $0.374^{\star * *}$ & $0.465^{\star \star *}$ & \\
\hline \multicolumn{2}{|c|}{ Criteria of structural model } & \multicolumn{2}{|c|}{ Rule of Thumb } & \multicolumn{2}{|l|}{ Statistic } \\
\hline \multirow{2}{*}{\multicolumn{2}{|c|}{$\begin{array}{l}\text { APC, ARS, AARS } \\
\text { AVIF, AFVIF }\end{array}$}} & \multicolumn{2}{|c|}{$P$-value $\leq 0.05$} & \multicolumn{2}{|c|}{$0.342^{\star \star \star} ; 0.413^{\star \star \star} ; 0.403^{* \star \star}$} \\
\hline & & $\leq 5$, ideally $\leq$ & & $1.874 ; 1.954$ & \\
\hline \multicolumn{2}{|l|}{ GoF } & \multicolumn{2}{|c|}{ Small $\geq 0.10$ medium $\geq 0.25$, large $\geq 0.36$} & \multicolumn{2}{|l|}{0.548} \\
\hline \multicolumn{2}{|l|}{ SPR, RSCR } & \multicolumn{2}{|c|}{$\geq 0.7$, ideally $=1$} & \multicolumn{2}{|l|}{$1 ; 1$} \\
\hline \multicolumn{2}{|l|}{ SSR, NLBCDR } & \multicolumn{2}{|l|}{$\geq 0.7$} & \multicolumn{2}{|l|}{$1 ; 1$} \\
\hline
\end{tabular}

MCS has a positive and significant effect on competitive advantage $(p<0.01)$, which provides support for H3. This result supports the argument of Henri (2006) that MCS functions as a valuable, rare, and inimitable resource and capability of a firm that helps firms to achieve and enhance competitive advantage. For the relationship between MCS and firm performance, the structural model shows that the use of MCS has a positive and significant effect on firm performance ( $p$ $<0.01$ ); providing support for $\mathrm{H} 4$. This shows that the use of MCS that aligned with the organizational context will improve firm performance. Finally, this result supports the last hypothesis (H5) which states that competitive advantage has a positive influence on firm performance $(p$ $<0.01)$. 


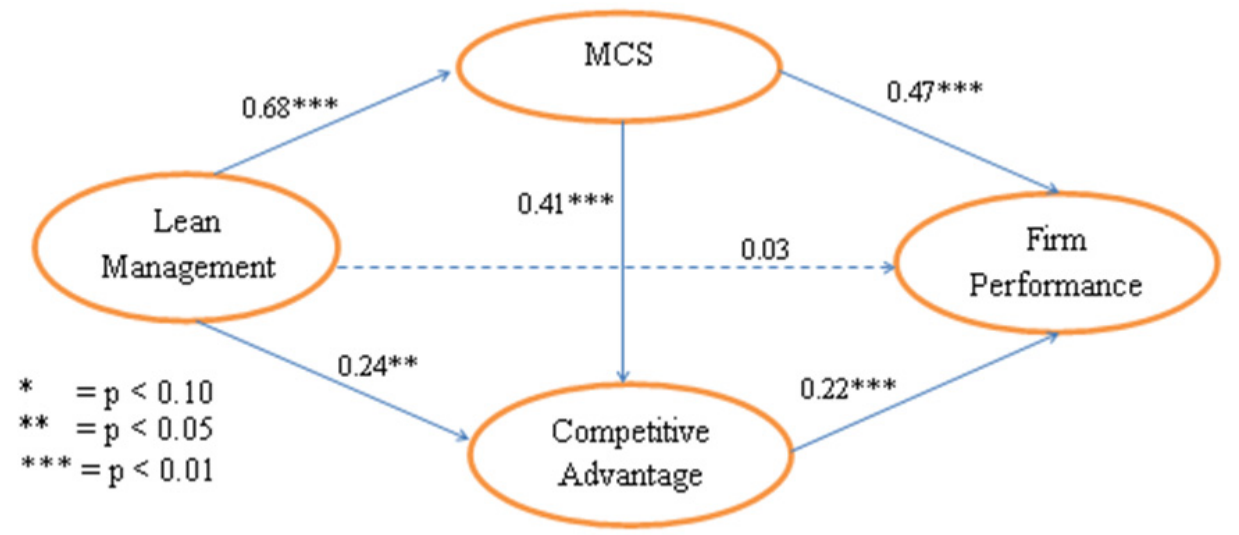

Figure 2: Partial least squre model: path coefficients for lean management, management control systems (MCS), competitive advantage, and firm performance

The results of the structural model in Figure. 2 show how intervening variables act as full mediators or partial mediators in the relationship between latent constructs (Baron \& Kenny, 1986). MCS and competitive advantage are full mediator variables for the relationship between lean management strategies and firm performance. MCS acts as a partial mediating variable for the relationship between lean management and competitive advantage. While competitive advantage functions as a partial mediating variable for the relationship between lean MCS and firm performance.

\section{Discussion and Conclusion}

In a structural model, the application of lean management strategies supported by an appropriate MCS will lead to the achievement of competitive advantage, which in turn, improves firm performance. This study provides several contributions to the current literature. First, the results of this study provide preliminary empirical evidence of the relationship between lean management strategies, MCS, competitive advantage, and firm performance. In the RBV perspective, an organization will be able to achieve a competitive advantage when the organization has valuable, rare and inimitable resources and capabilities that can sustain the implementation of strategies to create value. MCS is proven to be a resource and capability of a firm that supports the firm in implementing lean management strategies. MCS also shows a significant influence on competitive advantage and firm performance. This result is consistent with Henri (2006) who show that MCS is a valuable, rare and inimitable resource to promote competitive advantage. Furthermore, this study provides evidence that the firm can increase the benefits derived from the implementation of lean management by implementing a control system that aligned with the context of lean organizations. This study has several limitations. First, the data about a firm that fully implement lean management strategies are unavailable. Instead, this study uses the assumption of implementing lean management based on ownership of ISO 9001 certification. Second, the samples of this study are too small and merely use the manufacturing industry as a sample. Research with a larger sample and using a variety of industries are expected to provide more comprehensive evidence on this issue. Third, this research is based on cross-sectional data. Although the results of the analysis provide evidence of statistical relationships supported by the underlying theory, it is not strong enough as evidence of a causal relationship. Therefore, research with experimental methods or longitudinal studies that can control causality can be used to test this issue. To provide more comprehensive results from the RBV perspective related to this issue, further research may examine the relationship between lean management and MCS by including variables of market orientation, innovation, organizational learning, and entrepreneurship that Henri (2006) stated as the main capabilities for creating excellence competitive and improving firm performance. 


\section{Acknowledgment}

The authors would like to thank the Ministry of Research, Technology and Higher Education of the Republic of Indonesia for funding support to carry out this research.

\section{References}

Ahlstrom, P., \& Karlsson, C. (1996). Change Processes Towards Lean Production: The Role of Management Accounting System. International Journal of Operation \& Production Management, 16(11), 42-56.

Amit, R., \& Schoemaker, P. J. (1993). Strategic assets and organizational rent. Strategic management Journal, 14(1), 33-46.

Amoako-Gyampah, K., \& Acquaah, M. (2008). Manufacturing Strategy, Competitive Strategy, and Firm Performance: An Empirical Study in a Developing Economy Environment. Int. J. Production Economics, 111, 575-592.

Barney, J. (1991). Firm resources and sustained competitive advantage. Journal of Management, 17(1), 99-120.

Barney, J. B. (1986). Strategic factor markets: Expectations, luck, and business strategy. Management Science, 32(10), 1231-1241.

Baron, R. M., \& Kenny, D. A. (1986). The moderator-mediator variable distinction in social psychological research: Conceptual, strategic, and statistical considerations. Journal of personality and social psychology, 51(6), 1173.

Bhasin, S. (2012). An Appropriate Change Strategy for Lean Success. Management Decision, 50(3), 439-458. doi: 10.1108/00251741211216223

Callen, J. L., Fader, C., \& Krinsky, I. (2000). Just-in-Time: A Cross-sectional Plant Analysis. Int. J. Production Economics, 63, 277-301.

Chenhall, R. H. (2005). Integrative Strategic Performance Measurement Systems, Strategic Alignment of Manufacturing, Learning and Strategic Outcomes: An Exploratory Study. Accounting, Organizations and Society, 30, 395-442. doi: 10.1016/j.aos.2004.08.001

Chi, T., Kilduff, P. P. D., \& Gargeya, V. B. (2009). Alignment Between Business Environment Characteristics, Competitive Priorities, Supply Chain Structures, and Firm Business Performance. International Journal of Productivity \& Performance Management, 58(7), 645-669.

Flynn, B. B., Schroeder, R. G., \& Sakakibara, S. (1995). The Impact of Quality Management Practices on Performance and Competitive Advantage. Decision Sciences, 26(5), 659-691.

Fornell, C., \& Larcker, D. F. (1981). Evaluating structural equation models with unobservable variables and measurement error. Journal of marketing research, 39-50, Retrieved on 22 june 2016, from http://www.jstor.org/stable/3151312.

Fullerton, R. R., Kennedy, F. A., \& Widener, S. K. (2013). Management accounting and control practices in lean manufacturing environment. Accounting, Organizations and Society, 38, 50-71. doi: 10.1016/j.aos.2012.10.001

Fullerton, R. R., Kennedy, F. A., \& Widener, S. K. (2014). Lean manufacturing and firm performance: The incremental contribution of lean management accounting practices. Journal of Operations Management, 32, 414-428. doi: 10.1016/j.jom.2014.09.002

Fullerton, R. R., \& McWatters, C. S. (2002). The Role of Performance Measure and Incentive Systems in Relation to the Degree of JIT Implementation Accounting, Organizations and Society, 27, 711-735.

Fullerton, R. R., \& Wempe, W. F. (2009). Lean Manufacturing, Non-Financial Performance Measures, and Financial Performance. International Journal of Operation \& Production Management, 29(3), 214-240. doi: $10.1108 / 01443570910938970$

Hair Jr, J. F., Hult, G. T. M., Ringle, C., \& Sarstedt, M. (2014). A primer on partial least squares structural equation modeling (PLS-SEM): Sage Publications.

Henri, J.-F. (2006). Management control systems and strategy: A resource-based perspective. Accounting, Organizations and Society, 31(6), 529-558.

$\mathrm{Hu}$, Q., Mason, R., Williams, S., \& Found, P. (2015). Lean Implementation within SMEs: A Literature Review. Journal of Manufacturing Technology Management, 26(7), 980-1012.

Kennedy, F., \& Brewer, P. (2007). Motivating Employee Performance in Lean Environments: Respect, Empower, Support. In J. Stenzel (Ed.), Lean accounting: best practices for sustainable integration (pp. 93118). Hoboken, New Jersey: John Wiley \& Sons Inc.

Kennedy, F. A., \& Brewer, P. C. (2006). The Lean Enterprise and Traditional Accounting - Is the Honeymoon Over? The Journal of Corporate Accounting \& Finance, 63-74. doi: 10.1002/jcaf.20234

Kennedy, F. A., \& Widener, S. K. (2008). A control framework: Insights from evidence on lean accounting. Management Accounting Research, 19, 301-323. doi: 10.1016/j.mar.2008.01.001

King, A. A., \& Lenox, M. J. (2001). Lean and green? An empirical examination of the relationship between lean production and environmental performance. Production and operations management, 10(3), 244-256. 
Kock, N. (2010). Using WarpPLS in e-collaboration studies: An overview of five main analysis steps. International Journal of e-Collaboration (IJeC), 6(4), 1-11. doi: 10.4018/jec.2010100101

Kock, N. (2011). Using WarpPLS in e-collaboration studies: Mediating effects, control and second order variables, and algorithm choices. International Journal of e-Collaboration (IJeC), 7(3), 1-13. doi: 10.4018/jec.2011040101

Kristensen, T. B., \& Israelsen, P. (2014). Performance effects of multiple control forms in lean organization: a quantitative case study in systems fit approach. Management Accounting Research, 25, 45-62.

Lewis, M. A. (2000). Lean production and sustainable competitive advantage. International Journal of Operations \& Production Management, 20(8), 959-978. doi: 10.1108/01443570010332971

Li, S., Ragu-Nathan, B., Ragu-Nathan, T. S., \& Rao, S. S. (2006). The Impact of Supply Chain Management Practices on Competitive Advantage and Organizational Performance. Omega, International Journal of Management Science, 34, 107-124.

Marodin, G., German, A., Tortorella, F. G., \& Saurin, T. A. (2016). Contextual Factors and Lean Production Implementation in the Brazilian Automotive Supply Chain. Supply Chain Management: An International Journal, 21(4). doi: 10.1108/SCM-05-2015-0170

Maskell, B., Baggaley, B., \& Grasso, L. (2012). Practical Lean Accounting: A Proven System for Measuring and Managing the Lean Enterprise (2nd Ed) (Second Ed ed.). Boca Raton, FL: CRC Press.

Maskell, B. H., \& Baggaley, B. L. (2006). Lean Accounting: What's It All About? Target, 22, 1-43.

Maskell, B. H., \& Kennedy, F. A. (2007). Why Do We Need Lean Accounting and How Does It Work? Journal of Corporate Accounting \& Finance, 18(3), 59-73. doi: 10.1002/jcaf.20293

Nawanir, G., Kong Teong, L., \& Norezam Othman, S. (2013). Impact of lean practices on operations performance and business performance: some evidence from Indonesian manufacturing companies. Journal of Manufacturing Technology Management, 24(7), 1019-1050. doi: 10.1108/JMTM-03-2012-0027

Netland, T. H., Schloetzer, J. D., \& Ferdows, K. (2015). Implementing corporate lean programs: The effect of management control practices. Journal of Operations Management, 36, 90-102.

Perera, S., Harrison, G., \& Poole, M. (1997). Costumer-Focused Manufacturing Strategy and the Use of Operations-Based Non-Financial Performance Measures: A Research Note. Accounting, Organizations and Society, 22(6), 557-572.

Ringle, C. M., Sarstedt, M., \& Straub, D. (2012). A critical look at the use of PLS-SEM in MIS Quarterly. MIS Quarterly, 36(1), iii-xiv.

Rondeau, P. J., Vonderembse, M. A., \& Ragu-Nathan, T. S. (2000). Exploring Work System Practices for TimeBased Manufacturers: Their Impact on Competitive Capabilities. Journal of Operations Management, 18, 509-529.

Ruiz-de-Arbulo-Lopez, P., Fortuny-Santos, J., \& Cuatrecacas-Arbos, L. (2013). Lean Manufacturing: Costing the Value Stream. Industrial Management \& Data Systems, 113(5), 647-668. doi: 10.1108/02635571311324124

Shah, R., \& Ward, P. T. (2003). Lean manufacturing: context, practice bundles, and performance. Journal of Operations Management, 21, 129-149.

Shah, R., \& Ward, P. T. (2007). Defining and developing measures of lean production. Journal of Operations Management, 25, 785-805.

Spreitzer, G. M. (1995). Psychological Empowerment in Workplace: Dimensions, Measurement, and Validation. The Academy of Management Journal, 38(5), 1442-1465.

Thomas, K. W., \& Velthouse, B. A. (1990). Cognitive Elements of Empowerment: An "Interpretive" Model of Intrinsic Task Motivation. The Academy of Management Review, 15(4), 666-681.

Wernerfelt, B. (1984). A resource-based view of the firm. Strategic management Journal, 5(2), 171-180.

Widener, S. K. (2007). An Empirical Analysis of the Levers of Control Frameworks. Accounting, Organizations and Society, 32, 757-788.

Wilson, L. (2010). How To Implement Lean Manufacturing. New York,NY: McGraw-Hill.

Womack, J. P., \& Jones, D. T. (2003). Lean Thinking: Banish Waste and Create Wealth in Your Corporation. New York, NY: Free Press.

Wood, S., Stride, C., Wall, T. D., \& Clegg, C. W. (2004). Revisiting the use and effectiveness of modern management practices. Human Factors and Ergonomics in Manufacturing \& Service Industries, 14(4), 415-432.

Yang, M. G. M., Hong, P., \& Modi, S. B. (2011). Impact of lean manufacturing and environmental management on business performance: An empirical study of manufacturing firms. Int. J. Production Economics, 129, 251-261.

Youssef, M. A., \& Youssef, E. M. (2015). The synergisitic impact of time-based technologies on manufacturing competitive priorities. International Journal of Technology Management, 67(2-4), 245-268. 